\title{
Inciting Social Change through Film: Using Marcus Banks's Definition of Ethnographic Film to Discuss the Films of Participant Productions
}

Marie Loeb

Portland State University

Follow this and additional works at: https://pdxscholar.library.pdx.edu/mcnair Let us know how access to this document benefits you.

\section{Recommended Citation}

Loeb, Marie (2006) "Inciting Social Change through Film: Using Marcus Banks's Definition of Ethnographic Film to Discuss the Films of Participant Productions," PSU McNair Scholars Online Journal: Vol. 2: Iss. 1, Article 25.

https://doi.org/10.15760/mcnair.2006.175

This open access Article is distributed under the terms of the Creative Commons Attribution-NonCommercialShareAlike 4.0 International License (CC BY-NC-SA 4.0). All documents in PDXScholar should meet accessibility standards. If we can make this document more accessible to you, contact our team. 
Portland State University McNair Research Journal 2006-2008

Inciting Social Change through Film: Using Marcus Banks's Definition of Ethnographic Film to Discuss the Films of Participant Productions

by

Marie Loeb

\section{Faculty Mentor:}

Janice Haaken

Citation: Loeb, Marie. Inciting Social Change through Film: Using Marcus Banks's Definition of Ethnographic Film to Discuss the Films of Participant Productions. Portland State University McNair Scholars Online Journal, Vol. 2, 2006-2008: pages [175-185]. 


\title{
Inciting Social Change Through Film: \\ Using Marcus Banks's Definition of Ethnographic Film to Discuss the Films of Participant Productions
}

MARIE LOEB

JANICE HAAKEN, FACULTY MENTOR

\begin{abstract}
This article examines films produced by Participant Productions: Murderball, Good

Night, and Good Luck, North Country, Syriana, and An Inconvenient Truth, using the three aspects-Intention, Event, and Reaction as outlined by Marcus Banks (1992) to define an ethnographic film.
\end{abstract}

\section{Introduction}

Ethnographic films cannot be said to constitute a genre, nor is ethnographic filmmaking a discipline with unified origins and an established methodology. (MacDougall, 1978, p. 405)

While ethnographic films lack established methodology or markers of genre there are several assumed characteristics of an ethnographic film. The general understanding of an ethnographic film is that it is a non-fictional portrayal of a group of people for the understanding of society at large. Marcus Banks suggests that an ethnographic film should be defined using three aspects, "an intention - to make a film - results in an event - the filming process - which leads to a reaction - the response of the audience to the physical manifestation of the even (film)" (1992, p. 117). Banks examines not only the film itself, but also the filmmakers' intentions in creating the film and the audiences' reaction to the film.

"Intention" refers to the filmmakers' desire to capture "'reality' directly on the film strip" rather than allowing cinematography or a formulaic narrative to overtake the production (p. 119). A strict adherence to "reality" implies that the film cannot favor certain 
individuals more than others or highlighting the more interesting ones, nor edit happenings out of sequences to create drama or relevance. This approach to filmmaking is extremely relevant to research projects, but would not fair well in the commercial film market that relies on captivating a paying audience.

The term "event" denotes the filming or taping of the happening studied; this includes the crew, researchers, director, et al that have infiltrated the naturally occurring happening (p. 120). Banks offers "core beliefs" in the creation of an ethnographic film; "the filmmakers should follow the action, rather than provoking it" all the while not be delusional in thinking they are not altering the "action" by their presence; shoot a "vast amount of film" rather than "highlights" and then edit it "to preserve whole sequences in their entirety"; and that the "less obvious the 'subject' a film has, the better; famous people or historic events should be avoided" (p. 123). These "core beliefs" may be appropriate for research focused ethnographic films, but commercial documentaries must rely on commercial success, which may be lackluster with a slow pace due to "whole sequences in their entirety."

Understanding your audience-who they are, what is the desired action of the viewers, and will this be used for educational or commercial purposes, is Banks's third and final defining term for ethnographic films_-"reaction" (p. 124-125). It is with this definition that one can attribute and discuss the elicited response from the audience and how is coincides or diverges with the aims of the filmmaker.

This article will apply Bank's defining aspects of “intention", “event”, and "reaction" to films outside the standard academic documentary genre, broadening the scope of the defining characteristics to aid as a lens in defining and discussing social action filmmaking, and specifically how it applies to the films released by Participant Productions. 


\section{Participant Productions}

"The movie is just the beginning." (Participant Productions, 2006).

Participant Productions is "a media company that focuses its support on "socially relevant, commercially viable" films” created by Jeff Skoll in January 2004 (Mlynek, 2004). Skoll began the company with $\$ 100$ million of his estimated $\$ 5$ billion in personal assets he earned as the writer of the business plan for eBay as its first employee. Producing award winning films such as: Murderball, Good Night, and Good Luck, North Country, and Syriana Participant Productions also has a predetermined social cause for each film helping inspired audiences to act.

Murderball: “A [documentary] film about tough, highly competitive [Paralympics] rugby players. Quadriplegic rugby players" is not only an award winning film, but also a tool for social action (Participant Productions, 2006). Participant Production's website features an invitation to "take action" on the front page of their website which links the visitor to a cause for every film they release. For Murderball, Participant Productions offers the visitor to host a screening of the film and includes a guide to "Disability Etiquette" by the United Spinal Association and a "Murderball Discussion Guide" giving the host basic information on living with a disability and offers discussion questions including, "What can be done to change attitudes and stereotypes about people with disabilities in your community?" and "How can we turn the momentum from this screening and discussion into effective action?" (Participant Productions, 2006).

Good Night, and Good Luck is a standard narrative film that "chronicles [...] television news man Edward R. Murrow" as he and the members of the CBS newsroom "defy corporate and sponsorship pressures to examine the lies and scaremongering tactics perpetrated by McCarthy during his communist "witch-hunts"' (Participant Productions, 
2006). The corresponding campaign encourages the visitor to the website to "take action to help restore faith in the media's fundamental mission" explaining the "television and print news organizations have drifted away from hard news and toward entertainment designed to turn a profit with little accountability" (Participant Productions, 2005). Interested participants can join the community of citizen news watchdogs and report their own news on Participant's site, Participate.net/reportitnow.

"A campaign to end Sexual Harassment and Domestic Violence" is the activism arm of the film North Country; a narrative film about “the nation's first-ever class action lawsuit for sexual harassment" (Participant Productions, 2005). The website for the campaign offers a myriad of materials for a diverse group of site visitors. Available materials include a brochure with advice for parents to help them provide the tools to their sons to not be abusers, a fact sheet on domestic violence, and a "school sexual harassment policy checklist" (Participant Productions, 2006).

The narrative film, Syriana depicts the United States' dependence on foreign oil and the crisis at hand in regards to "our environment, economy, and national security" (Participant Productions, 2006). The campaign's website offers many options for activism including an invitation for interested parties to "join the virtual march to stop global warming," donate to renewable energy alternatives, and write letters to the oil distribution companies asking for public disclosure of payments and contracts with "oil producing companies" (Participant Productions, 2005).

Global warming is the subject of the documentary, An Inconvenient Truth, which shows scientific evidence to illustrate that "we have just ten years to avert a major catastrophe that could send our entire planet's climate system into a tail-spin off epic destruction" (Participant Productions, 2006). The "take action" portion of the website links 
to climatecrisis.net, a site that, among other things, calculates the visitor's output of carbon dioxide and gives many suggestions to reduce that output. The website also invites the visitor to become an activist in the campaign with "some simple things you can do to spread the word" (Gore, 2006).

\section{Discussion}

A key difference between ethnographic film and fictional narratives is a desired social reaction of social change rather than mere box office dollars. Participant Production combines both of these goals-box office success and positive social change, thus becoming the perfect company set the precedent for activism through film. One can make an inspiring film to illuminate a societal cause, but if no one sees it, limited change can precipitate.

Banks's defining characteristics for ethnographic film is an appropriate lens to examine Participant Productions, because in both cases the films are cause oriented. "Intention" as described previously could not possibly apply to a film company struggling to make a profit. By strictly adhering to "reality" there would be limited box office appeal and the cause behind the film would get little recognition. However, Participant Productions does release documentary films and although dramatized with slow motion, music, and other cinematic effects the filmmakers never create a new reality based on the footage. The filmmakers work closely with the participants in the documentary to create a reality as they see it.

In the case of fictional narrative films Participant Productions sets out to construct a reality that could exist, either based upon historical happenings or the future implications of our current political climate. While Banks referred to an intention to capture reality as it exists at the time of filming, Participant Productions, chooses to construct a reality with actors and sets. When a documentary filmmaker whittles down hundreds of hours of 
footage into a feature length film of roughly 80 minutes the filmmaker has to make hard choices as to what select images best convey the message of the film in the time allotted. Ultimately, a documentary filmmaker creates their own version of reality and thus minimizes the difference between reality and fantasy. Given an inevitable influence of perception in filmmaking, the fictionalized reality the production crew creates on the set is only marginally more fanciful that the final edited output of a documentary production.

Banks refers to the intended social reaction of ethnographic films as educational tools to increase understanding and empathy towards the group being depicted (pp. 124126). However, past the general awareness of the group Banks gives no tangible social action to strive for in the creation of an ethnographic film. In applying Banks's term, "reaction" more broadly to encompass all styles of filmmaking, the films of Participant Productions meet the initial requirements of Banks to educate, and then take it a step further to create social action campaigns for each of the films.

These campaigns are designed to give a voice to issues that resonate in the films. We partner with social sector organizations, non-profits and corporations who are committed to creating an open forum for discussion, educations and who can, in partnership with Participant, offer specific ways for audience members to get involved and to take action. (Participant Productions, 2006)

Jeff Skoll had, in an interview in Esquire, said that, "Books are good, yes, but how do people actually get most of their stories nowadays? Film and TV" (as cited in Sager, 2005).

\section{Conclusion}

Participant Productions is not the only film company producing social action films for the enjoyment of a mainstream audience, however, they are the only company succeeding as a business while still producing film intended to elicit a reaction of activism. 
In comparing the films produced by Participant Products and other social action films Bank's defining characteristics for ethnographic film offers a sturdy lens to discuss the Intention, Event, and Reaction of the production companies, the filmmakers, and the film itself. 
Banks, M. (1993, June). Visual anthropology and ethnographic film in British anthropology departments. Anthropology Today, 9(3), 21-22. Retrieved September 11, 2006, from JSTOR database.

Banks, M. (1988, October). The non-transparency of ethnographic film. Anthropology Today, 4(5), 2-3. Retrieved September 11, 2006, from JSTOR database.

Banks, M. (1992). Which films are ethnographic films?. In P. Crawford, \& D. Turton (Ed.), Film as Ethnography (pp. 116-129). Manchester, England: Manchester University Press.

Bing- Canar, J., \& Zerkel, M. (1998, Spring). Reading the media and myself: experiences in critical media literacy with young Arab-America women. Signs, 23(3), 735-743. Retrieved September 11, 2006, from JSTOR database.

Chanan, M. (2005). Documentary, public sphere and education: new video documentary in Argentina. Journal of Media Practice, 6(2), 113-116. Retrieved August 14, 2006, from Academic Search Premier database.

Cohen, J. (2006). Murderball discussion guide. United Spinal Association. Retrieved September 27, 2006, from http://participate.net/getintothegame/discussiontools

Corner, J. (2000). What can we say about 'documentay'?. Media, Culture \& Society, 22, 681688. Retrieved September 11, 2006, from SAGE Publications database.

Dornfeld, B. (1992, Winter). Representation and authority in ethnographic film/video:reception. Ethnomusicology, 36(1), 95-98. Retrieved September 11, 2006, from JSTOR database.

Eaton, M. (1992, December). Third international festival of ethnographic film. Anthropology Today, 8(6), 23-24. Retrieved September 11, 2006, from JSTOR database. 
Edwards, E. (2001, Spring). To be rather than to seem: liberal education \& personal growth through documentary production. Journal of Film and Video 53(1), 9-19. Retrieved September 11, 2006 from Academic Search Premier database.

Family Violence Prevention Fund. (2004). Coaching boys into men: your role in ending violence against women. Retrieved September 27, 2006 from http://paticipate.net/standup

Family Violence Prevention Fund. (n.d.). The facts on domestic abuse. Retrieved September 27, 2006 from http://paticipate.net/standup

Gore, A. (n.d.). See the truth. Retrieved September 27, 2006 from http:/ /www.climatecrisis.net/takeaction

Gore, A. (n.d.). Help bring about change locally, nationally and internationally. Retrieved September 27, 2006 from http://www.climatecrisis.net/takeaction/becomeactive Gore, A. (n.d.). Ten things to do. Retrieved September 27, 2006 from http://www.climatecrisis.net/takeaction

Henson, P., \& Schorzman, T. (1991, September). Videohistory: focusing on the American past. The Journal of American History, 78(2), 618-627. Retrieved September 11, 2006 from JSTOR database.

Lashinsky, A. (2005, March). Ebay's first hire goes to the movies. Fortune, $151(5), 36$. Retrieved September 20, 2006 from Academic Search Premier database.

Loizos, P. (1991, February). Some films on death and their ethnographic merits. Anthropology Today, 7(1), 3-10. Retrieved September 11, 2006 from JSTOR database.

MacDougall, D. (1978). Ethnographic film: failure and promise. Annual Review of Anthropology, 7, 405-425. Retrieved September 11, 2006, from JSTOR database. 
Mayer, V. (2001). When the camera won't focus: tensions in media ethnography. Feminist Media Studies, 1(3), 307-322). Retrieved January 1, 2006, from Academic Search Premier database.

Mlynek, A. (2004, December). Arts patrons. Canadian Business, 77(24), 45. Retrieved September 20, 2006, from Academic Search Premier database.

Nichols, B. (1987, Autumn). History, myth, and narrative in documentary. Film Quarterly, 41(1), 9-20. Retrieved September 11, 2006, from JSTOR database.

Olijnyk, Z. (2005, December). The movie mogul. Canadian Business, 78(24), 33. Retrieved September 20, 2006, from Academic Search Premier database.

Participant Productions. (2006). About Participant. Retrieved September 24, 2006, from http://www.participantproductions.com/company/about+participant

Participant Productions. (2006). About participate.net. Retrieved September 20, 2006, from http://participate.net/about

Participant Productions. (2006). A campaign to end sexual harassment and domestic violence. Retrieved September 27, 2006, from http://participate.net/standup Participant Productions. (2006). A campaign to end sexual harassment and domestic violence: North Country. Retrieved September 27, 2006, from http://participate.net/standup/aboutthefilm

Participant Productions. (2006). An Inconvenient Truth overview. Retrieved September 27, 2006, from http://www.participantproductions.com/films

Participant Productions. (2006). Changing the world one story at a time. Retrieved September 24, 2006, from http://www.participantproductions.com Participant Productions. (2006). Good Night, and Good Luck overview. Retrieved September 27, 2006, from http://www.participantproductions.com/films 
Participant Productions. (2006). Murderball discussion guide. Retrieved September 24, 2006, from http://participate.net/getintothegame/discussiontools

Participant Productions. (2006). Murderball overview. Retrieved September 24, 2006, from http://www.participantproductions.com/films

Participant Productions. (2006). Reduce your car's oil impact with TerraPass. Retrieved September 27, 2006, from http://participate.net/terrapass

Participant Productions. (2006). School sexual harassment policy checklist. Retrieved

September 27, 2006, from http://participate.net/standup

Participant Productions. (2006). Syriana overview. Retrieved September 27, 2006, from http:/ / www.participantproductions.com/films

Participant Productions. (2006). Take the media into your own hands. Retrieved September 27, 2006, from http:/ / participate.net/reportitnow/issue

Participant Productions. (2006). Tell oil companies to help stop corruption. Retrieved September 27, 2006, from http://participate.net/publishwhatyoupay

Participant Productions. (2006). Winning should be the only challenge. Retrieved September 24, 2006, from http://participate.net/getintothegame/issue

Sager, Mike. (2005, December). Jeff Skoll. Esquire, 144(6), 205. Retrieved September 20, 2006, from Academic Search Premier database.

Simco, N., \& Warin, J. (1997, December). Validity in image-based research: an elaborated illustration of the issues. British Educational Research Journal, 23(5), 661-672. Retrieved September 11, 2006, from JSTOR database.

Taylor, C. (2005, November). Social Redeemer. US News and World Report, 139(17), EE10EE12. Retrieved September 20, 2006, from Academic Search Premier database. 